\title{
Assessment of Indoor and Outdoor Radon Levels in South Lebanon
}

\author{
Mohammed A. Kobeissi • Omar El Samad • \\ Khaled Zahraman • Ibrahim Rachidi
}

Published online: 25 September 2014

(C) The Author(s) 2014. This article is published with open access at Springerlink.com

\begin{abstract}
The presence of high indoor radon concentrations, $C_{x}$, is a major concern of the public worldwide. Measurements of indoor radon in South Lebanon have been achieved using CR-39 detectors. $C_{x}$ values ranged between 30 and $122 \mathrm{~Bq} \mathrm{~m}^{-3}$ in one of the major towns in the area and are compared with measured atmospheric air Radon. Moderate seasonal variation of $C_{x}$ indoors has been observed, although $90 \%$ of the obtained indoor $C_{x}$ measurements are below $100 \mathrm{~Bq} \mathrm{~m}^{-3}$. Some homes produced $C_{x}$ readings above the permissible limit. Results showed that the ventilation effect played a major factor in reducing radon concentration levels indoors. Health assessment has been considered. Annual effective doses of radon varied from $1.01 \pm 0.10$ to $8.65 \pm 0.50 \mathrm{mSv} \mathrm{a}^{-1}$ in six homes in one of the four cases studied. These dosage values are above the permitted limit of $2.5 \mathrm{mSv} \mathrm{a}^{-1}$. Several types of granite contained in the studied homes were identified and their contributions to radon levels indoors were calculated.
\end{abstract}

Keywords Building materials - CR-39 - Effective dose $\cdot$ Granite exhalation rate $\cdot$ Lebanon - Radon risk assessment

M. A. Kobeissi $(\bowtie) \cdot$ O. El Samad · K. Zahraman Lebanese Atomic Energy Commission, National Council for Scientific Research, Riad Elsolh, Beirut, Lebanon e-mail: makobeissi@yahoo.com

I. Rachidi

Department of Physics, Faculty of Sciences (I), The Lebanese

University, Hadeth, Beirut, Lebanon

\section{Introduction}

The health impact of exposure to radon gas, ${ }^{222} \mathrm{Rn}$, inhalation by humans in the indoor environment is a major public concern worldwide. This exposure is due to emanation of radon gas from the decay chains of radioactive thorium $\left({ }^{232} \mathrm{Th}\right)$ and uranium $\left({ }^{238} \mathrm{U}\right)$, which are present in soil layers (Singh and Virk 1996; Sharma et al. 2003; Abdallah et al. 2007; Lawrence et al. 2009) and indoor construction materials, especially granite used as a countertop in kitchens or indoors as a decorative material (Kobeissi et al. 2013). The ${ }^{238} \mathrm{U}$ decay chain contains the most important radioactive elements, such as protactinium $\left({ }^{234} \mathrm{~Pa}\right)$, radium $\left({ }^{226} \mathrm{Ra}\right)$, radon $\left({ }^{222} \mathrm{Rn}\right)$, and bismuth $\left({ }^{214} \mathrm{Bi}\right)$.

The element ${ }^{226} \mathrm{Ra}$, with a half-life of 1,600 years, decays to ${ }^{222} \mathrm{Rn}$, by emitting $\alpha$-particles followed by $\gamma$ radiation. This means that the concentration of ${ }^{226} \mathrm{Ra}$ in building materials and in the soil layers determines the number of ${ }^{222} \mathrm{Rn}$ atoms concentrated in any home space. The element ${ }^{222} \mathrm{Rn}$ (indicated as $\mathrm{Rn}$ in the text), is the most important radioactive element due to its properties as an emitter of $\alpha$ particles with energy levels of $5.48 \mathrm{MeV}$, its half-life of 3.82 days, and its ability to penetrate through the ground and structural materials to reach the outdoor atmosphere and indoor spaces (Nazaroff and Nero 1988).

Inhalation of $\mathrm{Rn}$ through the internal respiratory tract exposes the lung tissues and their cells to the impact of radon's high energy alpha particles and its decay products. Such exposure for a long period can lead to pathological effects, such as respiratory functional changes and lung cancer. Risk of lung cancer rises by $16 \%$ for every increase of $100 \mathrm{~Bq} \mathrm{~m}^{-3}$ in indoor concentration as declared by the World Health Organization (WHO), which has led this organization to set the action level for residential $\mathrm{Rn}$ concentration at $100 \mathrm{~Bq} \mathrm{~m}^{-3}$ (WHO 2009). 
The health effects of $\mathrm{Rn}$ on citizens living in Rn-rich environments have motivated many researchers to conduct studies on indoor Rn concentration (Font et al. 1999; Singh et al. 2004; Barros-Dios et al. 2007; Nicolopoulos and Louizi 2008; Rahman et al. 2008; Singh et al. 2008). Studies of $\mathrm{Rn}$ exhalation from soil layers and building materials (Abu-Jarad et al. 1980; Khan et al. 1992; Maged and Borham 1997; Al-Jarallah 2001; El-Dine et al. 2001; El-Amri et al. 2003; Maged and Ashraf 2005; Mireles et al. 2007; Chen et al. 2010; Hassan et al. 2011), such as sand, grey and white cement, gypsum, paint, and granites (Kobeissi et al. 2008, 2013) also have been carried out. Granites used in kitchens as countertops and decorative material, particularly as a floor cover, also have been studied as Rn sources. Studies have shown that Rn exhalation rates from granites vary with their type and origin. Some granites exhale more $\mathrm{Rn}$ than other types of construction materials (Al-Jarallah 2001; Environmental Health and Engineering 2008; Nassiri et al. 2011; Kobeissi et al. 2013); this is due to a relatively high content of uranium and radium in natural granite rock formations.

Lebanon is a mountainous country with significantly low granite formations, but imports large amount of granite, and these rocks often are used as construction and decorative materials. But little is known about radon exposure inside or outside houses using granite materials. In Lebanon many home owners install granite in their kitchen as a countertop. A recent study has been conducted on the naturally occurring radioactive nuclides in sand, cement, gravel, gypsum, and paint (Kobeissi et al. 2008), as well as in granites (Kobeissi et al. 2013). Measurements of the indoor radon concentration in houses containing these materials or in nearby outdoor environments are still generally lacking. When measuring radon concentrations in kitchens, it is very appropriate to conduct concurrent measurement of radon exhalation rates from the granites used in such kitchens in order to evaluate their contribution to kitchen space radon contamination. This should lead the countries concerned to set up standards for acceptable levels of indoor environmental radiation.

This study measures radon concentration inside residential homes in one town and three villages in the study area in South Lebanon. This permits comparison of indoor results to construction materials used in the dwellings and to the presence of geological faults in the investigated area.

During the investigation, high quality photos were taken of the granite countertops in the kitchens. These photos were shown to two experienced and knowledgeable granite import dealers, who identified the name, type, and characteristics of each of the granites and the country of origin. $\mathrm{Rn}$ surface air exhalation rates obtained from the recorded corresponding granite materials were evaluated and their contributions to kitchen space radon levels were estimated.
The study results encourage further investigation that relates lung cancer to radon concentration levels in the public environment in the study area and recommends remedial actions to mitigate high radon levels in the investigated inner spaces of the dwellings.

Concurrently with the indoor measurements, atmospheric radon concentration around some of the studied dwellings was obtained and compared with the values achieved in the indoors measurements and worldwide results. Rn concentrations were determined during three seasons in the study area and ventilation as well as radon indoor-outdoor exchanges were considered. This work is a continuation of a long-term program to further investigate radon concentration as well as other occurring environmental radiation in order to establish standards for environmental radioactivity safety in the country.

\section{The Geographic Location of the Study Area}

The topographic and morphological structure of Lebanon consists of four parallel belts: the coastal belt, which runs on a narrow line along the East Mediterranean shoreline; the second belt, which is known as Mount Lebanon, is an uplifted mountain chain; the third structural area is the fertile Beka'a plain, which runs parallel to the east side of Mount Lebanon; and further to the East also paralleling Mount Lebanon, are the Anti-Lebanon Mountains, which form the fourth belt. This belt ends in South Lebanon with the volcanic Mount Hermon culminating at 2,820 m (Fig. 1).

This geological structure of Lebanon, is part of the larger geographical divisions of the Levant in which, for example, the Beka'a Valley forms an extension of the great Red Sea/Dead Sea Rift system (Walley 1988, 1998).This is manifested by a major fault line that spreads into five subfaults, some of which converge near the study area. The following towns are included in the indoor $\mathrm{Rn}$ concentration study:

(1) The Khiam Town: The town of Khiam lies in the Nabatiyeh Governorate in South Lebanon as shown in Fig. 1b. The town, with a population of 30,000 inhabitants and at an elevation of about $560 \mathrm{~m}$ above sea level, lies on the southwest side of Mount Hermon's peak on a north-south trending hill. This location is close to the Golan Heights basaltic formation that surrounds Mount Hermon. The west side of the town hill faces the extended plain of the Red Sea/Dead Sea Rift and is connected to it. One of the major faults, known as the Yammouneh Fault, passes near the west side of the town. 

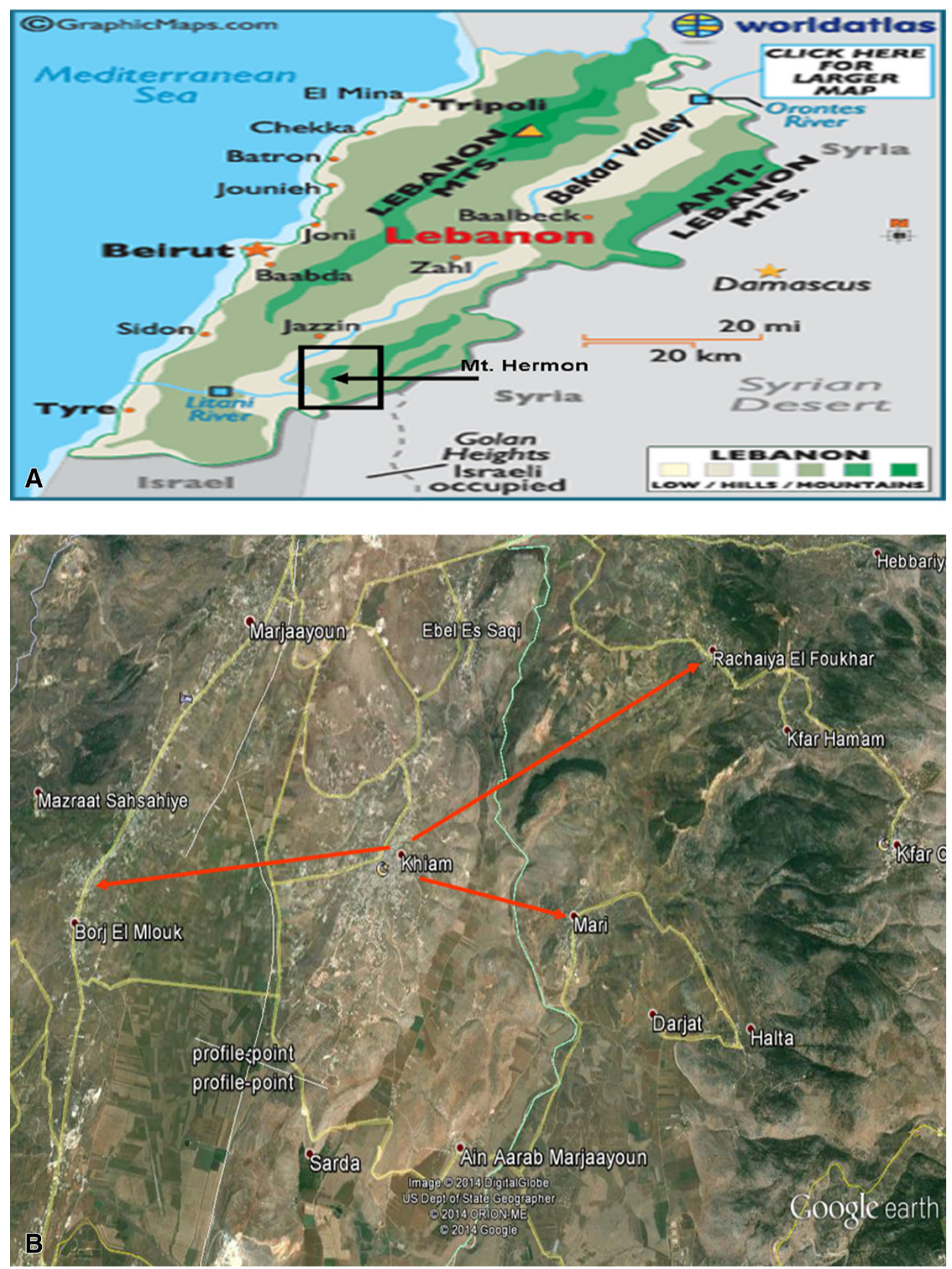

Fig. 1 Simplified map of Lebanon (a) from Worldatlas and the study area in South Lebanon (b). Litani River is about 15-18 km west of Khiam Town. Arrows originating from Khiam show the villages: Qlaiaa (5 km, it is $1 \mathrm{~km}$ north of Borj El Mlouk), Rachaiya El
Foukhar $(16 \mathrm{~km})$, and Mari $(15 \mathrm{~km})$. The distances are road distance. Source Worldatlas (http://www.worldatlas.com/webimage/countrys/ asia/lb.htm) (a); Google earth (https://www.google.com/earth/) (b) 
(2) The Qlaiaa village: This village is situated $1 \mathrm{~km}$ north of Borj El Mlouk (Fig. 1b) at the same altitude as Khiam, lies at the west edge of the Rift near the town of Marjaayoun, and at about $5 \mathrm{~km}$ from Khiam. Most of the homes studied in this town exist on its west side and are some distance away from the extended Rift.

(3) The Mari village: Mari village is located in a valley southeast of Khiam and at a distance of $15 \mathrm{~km}$ from Khiam Town. Its soil is mainly affected by the extension of the basaltic area from Mount Hermon that surrounds Mount Hermon.

(4) The Rachaiya El Foukhar village: This village lies at a distance $16 \mathrm{~km}$ northeast of Khiam. It has a population of about 3,000 residents in the summer, a population that declines to about 1,000 in the winter. The village is located on the western slopes of Mount Hermon at an altitude ranging from 800 to 1,250 $\mathrm{m}$ above sea level. Homes are spread randomly throughout the village's small area. This village was chosen for the study in order to test the effect of altitude on radon concentrations indoors.

\section{Experimental Procedure and Methodology}

In order to execute the present study, the cooperation of municipal officials of the towns was first secured. Brochures were then distributed to the residents explaining the health effects of high levels of radioactive radon gas. Residents were invited by the corresponding author to a lecture given in the cultural center of Khiam Town. This talk explained the procedure involved to set up radon detectors in their homes and answered any questions regarding the nature and origin of the radon gas and its health impact.

Information about the nature of the construction materials in the homes to be studied was obtained. The nature of the substrate and soil under and around the houses and the number of stories in each structure were recorded. Dwelling locations within the towns and the health situation of family members were noted. In addition, two well-trained and dedicated female graduate students in physics at the Faculty of Sciences of the Lebanese University took part in this study for the fulfillment of their Master's degrees.

\subsection{The CR-39 Detector and the Time Periods of Measurements}

Radon's indoor concentration is affected by the nature of the weathering in the geographical location, in addition to other factors. Seasonal change of the weather affects the behavior of the occupants of dwellings, such as closing or

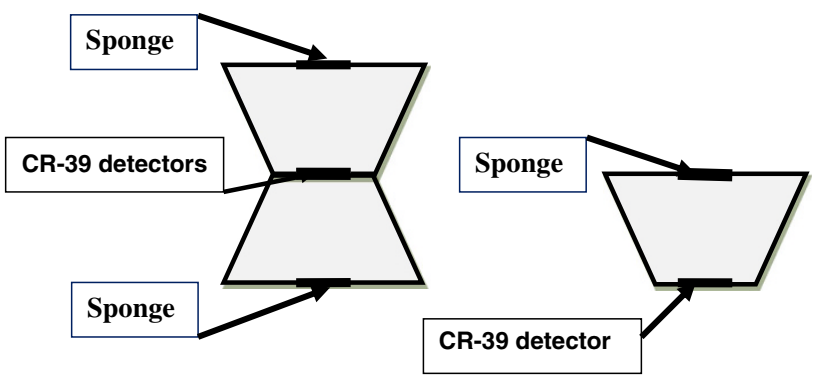

Fig. 2 Single and double dosimeters used for indoor and outdoor (single detector) measurements of radon gas to test $\mathrm{Rn}$ atomic weight effect

opening of windows or doors. Indoor seasonal $\mathrm{Rn}$ variability was observed by some researchers (Singh et al. 2001). Lebanon has a moderate seasonal weather change, especially in the study area. To test the seasonal effect, this research carried out experiments in three time intervals during the year 2010: Period I, from 27 February-7 June (mainly winter period); period II, from 7 June-18 September (mainly summer); and period III, from 18 September-25 December (autumn period). For indoor measurement of Rn, high quality CR-39 detectors have been used; these were obtained from Inter-cast Europe SRL (Italy). Quality assurance for this solid state nuclear track detector was achieved by taking part in an International Inter-Comparison process conducted by the Federal Office for Radiation Protection in Berlin, Germany. Each detector has dimensions of $2 \mathrm{~cm} \times 1.5 \mathrm{~cm}$ and a $1 \mathrm{~mm}$ thickness. The dosimeter, diagramed in Fig. 2, consists of a plastic cup with one side of the detector stuck in the bottom of its interior with a double sticker film. The cover of the cup is equipped with a $1 \mathrm{~cm}$ diameter circular hole, closed with a sponge as a filtering device to prevent the infiltration of dust and the alpha emitter radon, ${ }^{220} \mathrm{Rn}$. This type of cup dosimeter was used earlier (Kobeissi et al. 2008) so the team was experienced in its use and confident of its performance. Dosimeter calibration was done in the Federal Office for Radiation Protection in Berlin, Germany, with a calibration factor $K=150 \pm 12 \mathrm{~Bq} \mathrm{~m}^{-3} \mathrm{~h} /$ tracks $\mathrm{cm}^{-2}$ and with the final Eq. 1 given by:

$C_{x}=(150 \pm 12) \rho_{x} / t_{x}$

where $C_{x}, \rho_{x}$, and $t_{x}$ are Rn concentrations, track density on the CR-39 surface, and exposure time to Rn, respectively.

\subsection{Detectors Distribution Indoors in the Khiam Town and Rn Measurements}

The dosimeters were distributed in the dwellings of the town and were set in the bedrooms, the living rooms, the kitchens, and the bathrooms in each house. In many houses 
the bathroom was skipped due to the objections of the residents. The dosimeters were attached to the wall of the rooms by a solid wire at a height of about $180 \mathrm{~cm}$ from the floor and $30 \mathrm{~cm}$ from the wall surface, the doors, and the windows of each room. Double dosimeters were used only in time period I to test whether the entry of Rn (due to its higher atomic weight in the atmospheric air) into the dosimeter sponge depends on the orientation of the cup opening hole and whether that might have any effect on the result (Fig. 2).

It is well known that radon concentration levels in dwelling spaces depend on their geographical and geological locations. Thus the town was divided into four sections: Northern Zone (KH-1-KH-14), Southern Zone (KH-15-KH-22), Eastern Zone (KH-23-KH-37), and Western Zone (KH-38-KH-41). The letters KH are home codes in the town and the indices indicate the range in the number of the homes studied. The homes were chosen randomly in each zone and spaced no less than 50-100 m away from each other. The dosimeters were removed from the dwellings at the end of each time period and replaced by new ones. The detectors were etched in $7 \mathrm{~N} \mathrm{KOH}$ solution at $70{ }^{\circ} \mathrm{C}$ for eight hours followed by submerging them in an ultrasound water bath for $15 \mathrm{~min}$. A similar procedure was used for the other three villages in the study area.

\subsection{Rn Measurements in the Atmospheric Air}

For comparison with indoor radon concentrations, radon measurements in the atmospheric air in Khiam Town were undertaken as well. The dosimeters were set in a protective cylindrical PVC tube chambers, each chamber having $9 \mathrm{~cm}$ diameter and $7 \mathrm{~cm}$ height (area $A=6.36 \times 10^{-3} \mathrm{~m}^{2}$, volume $V=4.45 \times 1^{-4} \mathrm{~m}^{3}$ ). One open side of the chamber was hermetically closed with a screw top. The chamber was set in a welded ring attached to a metallic rod holder at $100 \mathrm{~cm}$ above the ground, with the open side of the chamber facing the ground surface. The same type of PVC tubes were used for the measurements of Rn exhalation rates in granitic tiles, as presented below.

\subsection{Radon Exhalation Rates from Surfaces of Granitic Tiles}

In recent publications, many concerns have been raised about the use of granitic tiles indoors, mainly in kitchens as countertops (Environmental Health and Engineering 2008; Kobeissi et al. 2013). For this purpose, tiles corresponding to the identified granites used in the homes studied were obtained from granite expert dealers for Rn emission measurements. These stones have a polished side with the opposite side retaining a rough surface, as is usual when

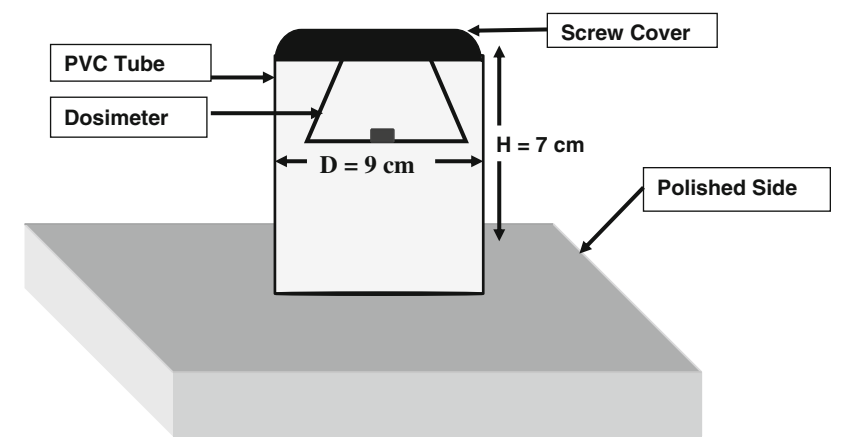

Fig. 3 Setup of the chamber dosimeter used on the polished side of the granitic tile. A similar dosimeter was set on the unpolished side

granite is used as a construction material in the study's villages and town. Each granitic tile has a dimension of $15 \times 15 \mathrm{~cm}$ with a $2 \mathrm{~cm}$ thickness.

$\mathrm{Rn}$ exhalation rates have been measured on both sides of the tiles in order to estimate granite contribution to the radon level in the kitchens of the chosen homes. The dosimeter was set in a cylindrical PVC tube chamber, as shown in Fig. 3. The open side of the tube was glued with high quality adhesive to the polished surface of the tile, while the other open side was hermetically closed with a screw top to prevent radon leakage. A similar setting was employed on the rough side surface of the tile, in order to investigate any variation of $\mathrm{Rn}$ exhalation rates from both surfaces of each granite type used as a construction material.

Radon aerial exhalation rates, $E_{A}\left(\mathrm{~Bq} \mathrm{~m}^{-2} \mathrm{~h}^{-1}\right)$, have been calculated using the following equation (Abu-Jarad et al. 1980; Khan et al. 1992; Maged and Borham 1997; Sharma et al. 2003):

$E_{A}=\left(C_{x} T V_{\mathrm{eff}} \lambda\right) /\left(A T_{c}\right)$,

where $T_{\mathrm{c}}=[T+(1 / \lambda)(\exp (-\lambda T)-1)]$. $T$ is the exposure time (in hours) of the CR-39 to Rn flux from the tiles surfaces, $C_{x}\left(\mathrm{~Bq} \mathrm{~m}^{-3}\right)$ is the radon concentration produced in the chamber, $V_{\text {eff }}\left(\mathrm{m}^{3}\right)$ is the effective volume of Rn gas contained in the PVC chamber, $\lambda(\mathrm{h})^{-1}$ is the decay constant of ${ }^{222} \mathrm{Rn}$, and $A\left(\mathrm{~m}^{2}\right)$ is the area covered by the chamber.

\section{Data Analysis Procedure}

For the evaluation of the density of alpha tracks, $\rho_{x}$, on the detector surface, the tracks were counted using a binocular microscope, where 20 views were taken for each detector with counts above 50 in each view in order to minimize statistical errors. The background was evaluated by measuring the tracks on five unexposed detectors as control, where the number of tracks ranged from 2 to 5 per view on 
the detector. The average value was then subtracted from the counts on the exposed detectors.

For appropriate statistical evaluation of the radon measurements, we have adopted a lognormal distribution analysis of the data. The geometric mean, $\mu_{\mathrm{g}}$, of the counted tracks in the 20 views for each detector was obtained. The standard deviation error, $\delta_{\mathrm{g}}$, on the geometric mean of the counted tracks in the 20 views was obtained by taking the geometric mean of the squared difference, $\left(X_{i}-\mu_{\mathrm{g}}\right)^{2}$, between the number of the tracks, $X_{i}$, in each view and the obtained geometric mean of the 20 views. In addition, and in order to evaluate the quality and homogeneity of the measurements, the data were transformed to lognormal scale, from which, the scale parameters, such as the means of the lognormal, $\mu_{\mathrm{ln}}$, and its standard deviation, $\sigma_{\mathrm{ln}}$, and the coefficient of the variance, $C v a=\left(\sigma_{\ln } / \mu_{\mathrm{ln}}\right)$, were obtained.

The tracks density, $\rho_{x}$, mentioned in Eq. 1 can be obtained from the geometric mean values, $\mu_{\mathrm{g}}$, so that Eq. 1 becomes:

$C_{x}=(150 \pm 12) \mu_{\mathrm{g}} / A t_{x}$,

where $A$ is the area of the viewed surface by the microscope on the detector.

\section{Results and Discussion}

Results of Rn concentration in the dwellings in Khiam Town as well as in the three villages and the atmospheric radon measurements are evaluated and presented in the following sections. Values of $\mathrm{Rn}$ exhalation rates obtained from granitic tiles and their contribution to kitchen space $\mathrm{Rn}$ concentration are listed and health assessment of $\mathrm{Rn}$ level effect on the inhabitants in the studied homes are discussed.

\subsection{Results of Rn Measurements for the Four Zones in Khiam Town}

Table 1 shows the results of averaged geometric means of Rn concentration, $C_{x}$, obtained from the study's three time intervals for each room in each zone. The error for $C_{x}$ was obtained from the deviation error, $\delta_{\mathrm{g}}$, on the geometric mean, $\mu_{\mathrm{g}}$, of the counted tracks, calculated by using Eq. 3 . The table shows also the averages of the arithmetic mean, $\mu_{\mathrm{ln}}$, of the lognormal distribution of alpha tracks data for each room, their corresponding standard deviation, $\sigma_{\mathrm{ln}}$, and the coefficient of variance, $\sigma_{\mathrm{ln}} / \mu_{\mathrm{ln}}$. The values of this coefficient show homogeneous distribution of the track measurements, and the good quality of the results is presented in the tendency toward the mean of the distribution, except in very few cases. Both the up and down orientation of the cup dosimeters, set in the first stage of measurement, each produced the same results of Rn concentration.

\subsubsection{The Case of the Northern Zone}

As presented in Table 1 for this zone, average Rn concentration, $C_{x}$, for the rooms in each dwelling is obtained from the three time intervals. They ranged between 32 and $133 \mathrm{~Bq} \mathrm{~m}^{-3}$ with an average of $43 \pm 3,26-115 \mathrm{~Bq} \mathrm{~m}^{-3}$ with an average of $37 \pm 4$, and $26-107 \mathrm{~Bq} \mathrm{~m}^{-3}$ with an average of $40 \pm 5 \mathrm{~Bq} \mathrm{~m}^{-3}$ for the bedrooms, the living rooms, and the kitchen spaces respectively. The total mean value for the zone was obtained as $42 \pm 5 \mathrm{~Bq} \mathrm{~m}^{-3}$. With the exception of two cases, (G-KH-2), and (G-KH-14), the coefficient of variance ranged from 0.02 to 0.13 indicating homogeneous radon distribution among the rooms in each dwelling within the experimental errors and showing that radon exchange took place among the rooms.

Nearly all $(90 \%)$ of the lognormal distributions produced a homogeneous distribution and a narrowing toward the means. Mean values in dwelling $\mathrm{KH}-7$ are given as $133 \pm 15,115 \pm 11$, and $107 \pm 11 \mathrm{~Bq} \mathrm{~m}^{-3}$, for the bedrooms, living rooms, and kitchen spaces respectively, with a total average of $118 \pm 11 \mathrm{~Bq} \mathrm{~m}^{-3}$. Radon concentration was found to be $275 \pm 30 \mathrm{~Bq} \mathrm{~m}^{-3}$ in the bathroom of dwelling $\mathrm{KH}-14$, which represents the highest reading in the zone. These high values in the zone are above the permissible safety limit of $100 \mathrm{~Bq} \mathrm{~m}$ m $^{-3}$ suggested by WHO.

The kitchen in dwelling $\mathrm{KH}-2$ and the bathroom in dwelling KH-14 produced the highest value in the dwellings, unlike the other rooms in the zone. The case of the bathroom could be due to whether the town supplied water carries dissolved $\mathrm{Rn}$ from the ground source, as was reported by some researchers on the presence of high radon content in the water source of the town (Abdallah et al. 2007).

\subsubsection{The Case of the Southern Zone}

The range of the average obtained from the three time intervals are: $22-64 \mathrm{~Bq} \mathrm{~m}^{-3}$, with an average of $31 \pm 3 \mathrm{~Bq} \mathrm{~m}^{-3}$ for the bed rooms, $18-59 \mathrm{~Bq} \mathrm{~m}^{-3}$ with an average of $28 \pm 2 \mathrm{~Bq} \mathrm{~m}^{-3}$ for the living rooms, $20-52 \mathrm{~Bq} \mathrm{~m}^{-3}$ with an average of $29 \pm 3 \mathrm{~Bq} \mathrm{~m}^{-3}$ for the kitchens, and $22-47 \mathrm{~Bq} \mathrm{~m}{ }^{-3}$ with an average of $33 \pm 3 \mathrm{~Bq} \mathrm{~m}^{-3}$ for the bathrooms, with the total average given as $30 \pm 8 \mathrm{~Bq} \mathrm{~m}^{-3}$ for the zone.

Table 1 shows also a homogeneous distribution of the data in this zone, as indicated in the values of the coefficient of variance, which ranges from 0.01 to 0.06 and shows a close narrowing toward the mean value of the lognormal distribution. Averages in the Southern zone are 
Table 1 Average geometric mean of Rn concentration, $C_{x}\left(\mathrm{~Bq} \mathrm{~m}^{-3}\right)$, obtained from the three stages of measurements in the rooms in each dwelling, arithmetic mean, $\mu_{\mathrm{ln}}$, and its standard deviation $\sigma_{\mathrm{ln}}$, as well as the coefficient of variance, $\sigma_{\mathrm{ln}} / \mu_{\mathrm{ln}}$, of the lognormal distribution of Rn measurements in Khiam Town

\begin{tabular}{|c|c|c|c|c|c|c|c|c|}
\hline Home code & Bedroom & Living room & Kitchen & Bathroom & Mean & $\mu_{\ln }$ & $\sigma_{\ln }$ & $\sigma_{\ln } / \mu_{\ln }$ \\
\hline \multicolumn{9}{|c|}{ Northern zone } \\
\hline KH-1 & $32 \pm 2$ & $40 \pm 2$ & $35 \pm 2$ & - & 36 & 3.570 & 0.112 & 0.03 \\
\hline G-KH-2 & $37 \pm 2$ & $34 \pm 2$ & $144 \pm 12$ & - & $56 \pm 4$ & 4.036 & 0.810 & 0.20 \\
\hline G-KH-3 & $34 \pm 2$ & $26 \pm 2$ & $36 \pm 2$ & $33 \pm 2$ & $32 \pm 2$ & 2.802 & 0.143 & 0.05 \\
\hline G-KH-4 & $63 \pm 2$ & $26 \pm 2$ & $29 \pm 2$ & - & $36 \pm 2$ & 3.590 & 0.483 & 0.14 \\
\hline KH-5 & $37 \pm 3$ & $32 \pm 2$ & $29 \pm 2$ & - & $32 \pm 2$ & 3.481 & 0.123 & 0.04 \\
\hline KH-6 & - & - & $26 \pm 2$ & - & $26 \pm 2$ & 3.258 & - & - \\
\hline G-KH-7 & $133 \pm 15$ & $115 \pm 11$ & $107 \pm 11$ & - & $118 \pm 11$ & 4.769 & 0.111 & 0.02 \\
\hline KH-8 & $33 \pm 3$ & $37 \pm 3$ & $36 \pm 3$ & - & $35 \pm 3$ & 3.564 & 0.060 & 0.02 \\
\hline G-KH-9 & $35 \pm 3$ & $28 \pm 3$ & $28 \pm 3$ & - & $30 \pm 3$ & 3.407 & 0.129 & 0.04 \\
\hline $\mathrm{KH}-10$ & $43 \pm 2$ & $31 \pm 2$ & $26 \pm 2$ & $56 \pm 3$ & $37 \pm 2$ & 2.964 & 0.342 & 0.12 \\
\hline G-KH-11 & $40 \pm 3$ & $34 \pm 2$ & $32 \pm 3$ & $58 \pm 3$ & $40 \pm 3$ & 3.685 & 0.267 & 0.07 \\
\hline G-KH-12 & - & $36 \pm 2$ & $33 \pm 2$ & $26 \pm 2$ & $31 \pm 2$ & 3.446 & 0.169 & 0.05 \\
\hline KH-13 & $47 \pm 3$ & $57 \pm 2$ & $70 \pm 3$ & $24 \pm 2$ & $46 \pm 3$ & 3.830 & 0.464 & 0.12 \\
\hline G-KH-14 & $37 \pm 2$ & $32 \pm 2$ & $30 \pm 2$ & $275 \pm 30$ & $70 \pm 12$ & 3.950 & 1.117 & 0.28 \\
\hline Mean & $43 \pm 3$ & $37 \pm 4$ & $40 \pm 5$ & $51 \pm 6$ & $42 \pm 5$ & 3.570 & - & 0.09 \\
\hline \multicolumn{9}{|c|}{ Southern zone } \\
\hline G-KH-15 & $18 \pm 3$ & $19 \pm 3$ & $20 \pm 3$ & - & $19 \pm 3$ & 2.944 & 0.053 & 0.02 \\
\hline $\mathrm{KH}-16$ & $64 \pm 3$ & $59 \pm 3$ & $52 \pm 3$ & - & $58 \pm 3$ & 4.063 & 0.105 & 0.03 \\
\hline G-KH-17 & $34 \pm 3$ & $31 \pm 3$ & $23 \pm 2$ & - & $29 \pm 3$ & 3.365 & 0.204 & 0.06 \\
\hline G-KH-18 & $42 \pm 2$ & $43 \pm 2$ & $35 \pm 2$ & $47 \pm 3$ & $41 \pm 2$ & 3.726 & 0.124 & 0.03 \\
\hline KH-19 & $26 \pm 3$ & $25 \pm 3$ & $27 \pm 3$ & $26 \pm 3$ & $26 \pm 3$ & 3.258 & 0.031 & 0.01 \\
\hline KH-20 & $23 \pm 2$ & $21 \pm 2$ & $20 \pm 2$ & $22 \pm 2$ & $21 \pm 2$ & 3.067 & 0.060 & 0.02 \\
\hline G-KH-21 & $22 \pm 2$ & $18 \pm 2$ & $20 \pm 2$ & - & $20 \pm 2$ & 2.992 & 0.100 & 0.03 \\
\hline G-KH-22 & $41 \pm 3$ & $31 \pm 2$ & $56 \pm 3$ & $42 \pm 3$ & $42 \pm 3$ & 3.728 & 0.242 & 0.07 \\
\hline Mean & $31 \pm 3$ & $28 \pm 2$ & $29 \pm 3$ & $33 \pm 3$ & $30 \pm 8$ & 2.944 & - & 0.02 \\
\hline \multicolumn{9}{|l|}{ Eastern zone } \\
\hline $\mathrm{KH}-23$ & $35 \pm 3$ & $36 \pm 3$ & $24 \pm 3$ & $28 \pm 3$ & $30 \pm 3$ & 3.412 & 0.192 & 0.06 \\
\hline G-KH-24 & $36 \pm 3$ & $28 \pm 3$ & $28 \pm 2$ & - & $30 \pm 3$ & 3.416 & 0.145 & 0.04 \\
\hline $\mathrm{KH}-25$ & $22 \pm 2$ & $28 \pm 3$ & $21 \pm 2$ & $23 \pm 3$ & $23 \pm 3$ & 3.151 & 0.127 & 0.04 \\
\hline $\mathrm{KH}-26$ & $26 \pm 2$ & $38 \pm 3$ & $30 \pm 3$ & - & $31 \pm 3$ & 3.432 & 0.192 & 0.06 \\
\hline G-KH-27 & $27 \pm 2$ & $25 \pm 2$ & $22 \pm 2$ & $25 \pm 2$ & $25 \pm 2$ & 3.206 & 0.085 & 0.03 \\
\hline $\mathrm{KH}-28$ & $25 \pm 2$ & $24 \pm 3$ & $24 \pm 2$ & $23 \pm 2$ & $24 \pm 2$ & 3.178 & 0.034 & 0.01 \\
\hline G-KH-29 & $30 \pm 3$ & $22 \pm 2$ & $26 \pm 3$ & $140 \pm 13$ & $40 \pm 4$ & 3.673 & 0.855 & 0.23 \\
\hline G-KH-30 & $130 \pm 13$ & $131 \pm 13$ & $172 \pm 13$ & - & $143 \pm 13$ & 4.963 & 0.159 & 0.03 \\
\hline G-KH-31 & $47 \pm 6$ & $39 \pm 3$ & $35 \pm 2$ & - & $40 \pm 4$ & 3.690 & 0.149 & 0.04 \\
\hline $\mathrm{KH}-32$ & $33 \pm 3$ & $27 \pm 2$ & $29 \pm 2$ & - & $30 \pm 3$ & 3.387 & 0.102 & 0.03 \\
\hline KH-33 & $24 \pm 2$ & $26 \pm 2$ & $29 \pm 2$ & - & $26 \pm 2$ & 3.268 & 0.095 & 0.03 \\
\hline KH-34 & $24 \pm 2$ & $16 \pm 2$ & $27 \pm 2$ & $38 \pm 3$ & $25 \pm 2$ & 3.221 & 0.357 & 0.11 \\
\hline G-KH-35 & $51 \pm 3$ & $33 \pm 3$ & $29 \pm 2$ & $41 \pm 3$ & $38 \pm 3$ & 3.627 & 0.248 & 0.07 \\
\hline G-KH-36 & $42 \pm 3$ & $29 \pm 2$ & $33 \pm 2$ & $33 \pm 2$ & $34 \pm 2$ & 3.524 & 0.155 & 0.04 \\
\hline G-KH-37 & $37 \pm 3$ & $33 \pm 2$ & $25 \pm 2$ & - & $31 \pm 2$ & 3.442 & 0.202 & 0.06 \\
\hline Mean & $35 \pm 3$ & $31 \pm 3$ & $31 \pm 3$ & $36 \pm 3$ & $33 \pm 5$ & - & - & 0.02 \\
\hline \multicolumn{9}{|c|}{ Western zone } \\
\hline G-KH-38 & $73 \pm 3$ & $39 \pm 2$ & $43 \pm 2$ & $48 \pm 4$ & $49 \pm 3$ & 3.897 & 0.276 & 0.07 \\
\hline G-KH-39 & $378 \pm 25$ & $286 \pm 15$ & $372 \pm 23$ & - & $343 \pm 20$ & 5.837 & 0.157 & 0.03 \\
\hline G-KH-40 & $65 \pm 3$ & $46 \pm 3$ & $53 \pm 3$ & $49 \pm 3$ & $53 \pm 3$ & 3.966 & 0.150 & 0.04 \\
\hline
\end{tabular}


Table 1 continued

\begin{tabular}{lcccccccc}
\hline Home code & Bedroom & Living room & Kitchen & Bathroom & Mean & $\mu_{\ln }$ & $\sigma_{\text {ln }}$ & $\sigma_{\ln } / \mu_{\text {ln }}$ \\
\hline G-KH-41 & $47 \pm 3$ & $31 \pm 3$ & $29 \pm 2$ & - & $35 \pm 3$ & 3.550 & 0.262 & 0.07 \\
Mean & $141 \pm 12$ & $101 \pm 11$ & $124 \pm 12$ & $40 \pm 3$ & $122 \pm 12$ & - & - \\
\hline
\end{tabular}

$G$ ground floor

somewhat lower than in the northern zone case, which shows dependence of $\mathrm{Rn}$ concentration on the studied location and area.

\subsubsection{The Case of the Eastern Zone}

In the Eastern Zone, the average $\mathrm{Rn}$ concentration ranged between 22 and $130 \mathrm{~Bq} \mathrm{~m}^{-3}$ with an average of $35 \pm 3 \mathrm{~Bq}$ $\mathrm{m}^{-3}$ for the bedroom, $16-131 \mathrm{~Bq} \mathrm{~m}^{-3}$ with an average of $31 \pm 3 \mathrm{~Bq} \mathrm{~m}^{-3}$ for the living room, 21-172 $\mathrm{Bq} \mathrm{m}^{-3}$ with an average of $31 \pm 3 \mathrm{~Bq} \mathrm{~m}^{-3}$ for the kitchen, and 23-140 $\mathrm{Bq} \mathrm{m}^{-3}$ with an average of $36 \pm 3 \mathrm{~Bq} \mathrm{~m}^{-3}$ for the bathroom. A total mean value of $33 \pm 5 \mathrm{~Bq} \mathrm{~m}^{-3}$ was calculated for the Eastern Zone, which is slightly lower than in the Northern Zone. Dwelling KH-29 produced a radon concentration of $140 \pm 13 \mathrm{~Bq} \mathrm{~m}^{-3}$ in the bathroom.

Dwelling KH-30 generated a high average radon concentration of $130 \pm 13,131 \pm 13$, and $172 \pm 13 \mathrm{~Bq} \mathrm{~m}^{-3}$ in its three principle rooms, respectively, and a total average value of $143 \pm 13 \mathrm{~Bq} \mathrm{~m}^{-3}$. These are higher than the permissible value of $100 \mathrm{~Bq} \mathrm{~m}^{-3}$ set by WHO. The values of the coefficient of variance ranged between 0.01 and 0.11 , and had a narrowing tendency toward the mean parameter.

\subsubsection{The Case of the Western Zone}

One of the four homes in the western part of the town (Dwelling KH-39) showed much higher Rn concentration values than houses in the other sections. Ranges of the averaged radon concentration, obtained from the three time intervals for this section of the town, are given in Table 1 for the bedrooms, the living rooms, and the kitchens. These values varied between 47 and $378 \mathrm{~Bq} \mathrm{~m}^{-3}$ (averaged mean value $141 \pm 12 \mathrm{~Bq} \mathrm{~m}^{-3}$ ), 31-286 $\mathrm{Bq} \mathrm{m}^{-3}$ (averaged mean value $101 \pm 11 \mathrm{~Bq} \mathrm{~m}^{-3}$ ), and 29-372 $\mathrm{Bq} \mathrm{m}^{-3}$ (averaged mean value $124 \pm 12 \mathrm{~Bq} \mathrm{~m}^{-3}$ ), respectively, with a total zonal average calculated as $122 \pm 12 \mathrm{~Bq} \mathrm{~m}^{-3}$.

Dwelling KH-39 produced average values from the three time intervals that are $378 \pm 25,286 \pm 15$, and $372 \pm 23 \mathrm{~Bq} \mathrm{~m}^{-3}$, as it is listed in Table 1 , with a total average of $343 \pm 20 \mathrm{~Bq} \mathrm{~m}^{-3}$. These values are much higher than in the other zones of the town. This might be explained by the fact that this zone is located close to the extension of the great Red Sea/Dead Sea Rift in the area, which contains the Yammouneh Fault trace line close to the studied area of the west side of the town hill.

Thus the geological structure (the Yammouneh Fault) may have affected the level of radon concentration in the residential area. Therefore it is recommended that studies on dwellings located along the fault, or near it, should be carried out in future work. In order to properly assess the health impact of radon concentration on the residents of the studied homes, it is more appropriate to sort out the anomalous high $\mathrm{Rn}$ concentration in some individual homes so that such results and their health effects are not lost in the averaging process. Therefore, a detailed account of the high radon concentrations that occur in a few dwellings for each time interval of measurement in Khiam Town is presented in a later section in order to assess the health impact on the residents of these houses.

\subsubsection{Radon Seasonal Variation and Ventilation Effect}

Ventilation effect that has been monitored by some researchers (Singh et al. 2001), is an essential factor in reducing indoor $\mathrm{Rn}$ level. Measurements in winter time have shown an increase in $\mathrm{Rn}$ concentration and $\mathrm{Rn}$ concentration decreased in summer. In the present work, such effect is monitored by the measurements of $\mathrm{Rn}$ in the Northern Zone area in Khiam Town. Figure 4 presents the temporal variation of radon concentration in the kitchens in the Northern Zone location in Khiam Town during winter and summer seasons. Such effect did not occur in all the dwellings, due to the irregularity of the inhabitants residing in the dwellings, or the use of air conditioning in summer, as was observed during the measurements in dwellings KH-5 and KH-6 (Fig. 4). Therefore, caution must be taken when monitoring indoor radon levels in different seasons.

\subsection{Rn Concentrations Measured in the Three Villages}

Indoor measurements of radon concentrations, $C_{x}$, in Qlaiaa village (Fig. 1) have been studied in 10 dwellings. The averaged $C_{x}$ over the three time intervals ranged between 21.5 and $65 \mathrm{~Bq} \mathrm{~m}^{-3}$ for the bedrooms, with a total average of $38 \mathrm{~Bq} \mathrm{~m}^{-3}$. For the living rooms $C_{x}$ ranged between 23 and $56 \mathrm{~Bq} \mathrm{~m}^{-3}$ with a total average of $32 \mathrm{~Bq} \mathrm{~m}^{-3}$. For the kitchens, the range was between 22 and $66 \mathrm{~Bq} \mathrm{~m}^{-3}$ with a total average of $36 \mathrm{~Bq} \mathrm{~m}^{-3}$, and the 
Fig. 4 Radon levels increase in the winter season (series 1) and decrease in the summer (series 2 ), as seen also in the table

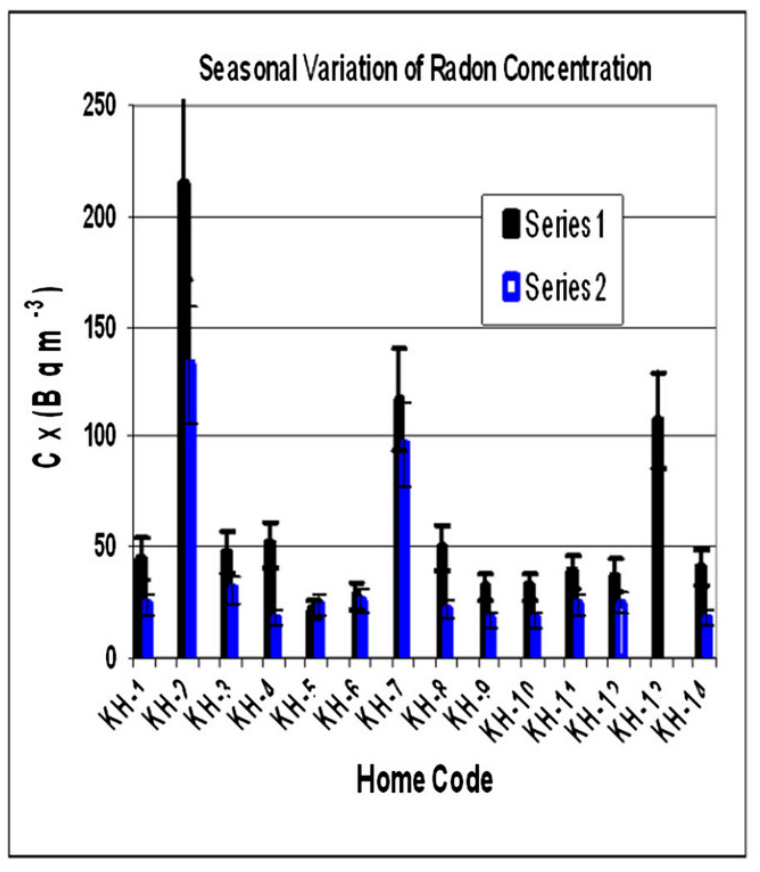

\begin{tabular}{|c|c|c|}
\hline \multicolumn{2}{|c|}{ Seasonal Variation of Rn Cx } \\
\hline Kitchen & \multicolumn{2}{|c|}{ Cx(Bqm $\left.{ }^{-3}\right)$} \\
\hline Home Code & Winter & Summer \\
\hline KH-1 & 45 & 24 \\
\hline KH-2 & 214 & 133 \\
\hline KH-3 & 47 & 31 \\
\hline KH-4 & 51 & 18 \\
\hline KH-5 & 22 & 24 \\
\hline KH-6 & 28 & 26 \\
\hline KH-7 & 117 & 96 \\
\hline KH-8 & 50 & 22 \\
\hline KH-9 & 32 & 17 \\
\hline KH-10 & 32 & 17 \\
\hline KH-11 & 39 & 24 \\
\hline KH-12 & 37 & 25 \\
\hline KH-13 & 107 & \\
\hline KH-14 & 41 & 18 \\
\hline & & \\
\hline
\end{tabular}

variance ranged between 0.02 and $0.04,0.02$ and 0.05 , and 0.01 and 0.05 for the bedrooms, the living rooms, and the kitchens, respectively. All the dwellings showed $C_{x}$ measurements below the standards set by the WHO.

Six homes were investigated in Mari village. Averages of $C_{x}$ for the bedrooms, the living rooms, and the kitchen spaces ranged between 26 and $76 \mathrm{~Bq} \mathrm{~m}^{-3}$ (average $39 \mathrm{~Bq} \mathrm{~m}^{-3}$ ), 30-56 $\mathrm{Bq} \mathrm{m}^{-3}$ (average $32 \mathrm{~Bq} \mathrm{~m}^{-3}$ ), and 29-60 Bq m$~^{-3}$ (average $36 \mathrm{~Bq} \mathrm{~m}^{-3}$ ) respectively. The variance ranged between 0.03 and $0.04,0.03$ and 0.07 , and 0.04 and 0.05 for the bedrooms, the living rooms, and kitchen spaces, respectively. Qlaiaa and Mari produced $C_{x}$ values that were close to each other as well as a homogenous distribution of $\mathrm{Rn}$ concentration among the rooms of each dwelling. These two villages lie on different geological formations: Mari is built on basaltic rock layers whereas Qlaiaa is not. The close level of $\mathrm{Rn}$ concentration between the two villages might be due to the fact that they use the same common building materials.

Measurements of $C_{x}$ in the village of Rachaiya ElFoukhar were carried out in five homes. Rn concentration, averaged over the three time intervals, ranged between 17 and $31 \mathrm{~Bq} \mathrm{~m}^{-3}$ (average 24), 20-34 $\mathrm{Bq} \mathrm{m}^{-3}$ (average $26 \mathrm{~Bq} \mathrm{~m}^{-3}$ ) and $19-34 \mathrm{~Bq} \mathrm{~m}^{-3}$ (average $25 \mathrm{~Bq} \mathrm{~m}^{-3}$ ) for the bedrooms, the living rooms, and the kitchen spaces, respectively. The total average measurement for Rachaiya El-Foukhar village was $25 \mathrm{~Bq} \mathrm{~m}^{-3}$. Rn concentrations showed lower values than in Khiam Town and in the other two villages. This behavior is well understood, due to its higher elevation, ranging from 750 to $1,250 \mathrm{~m}$ above sea level, and the lower air density at high altitude as compared with the other villages. This elevation effect factor was noticed also by Baros-Dios in Spain (Barros-Dios et al. 2007).

\section{Comparison with Results Obtained in Different Parts of the World}

It is well understood that indoor radon levels in different parts of the world depend on the geographical, geological, and climatic conditions and living habits in each country. Concerning the health effect of radon level on the public worldwide, it is appropriate and necessary to compare the results of the present work and data obtained with those obtained in other countries, some of which have similar climate as in Lebanon (such as Cyprus, Spain, Greece) and others are less similar (such as Germany, Pakistan, U.S., Canada, and U.K.).

Table 2 compares $\mathrm{Rn}$ concentrations indoors obtained in the present study with those measured in other countries. The table shows that the range of indoor radon concentration in South Lebanon is close to that obtained in dwellings in Spain, Greece, and the neighboring island of Cyprus (Nicolopoulos and Louizi 2008), which have a similar climate and living habits as does the Lebanese population with regard to home ventilation and dwelling construction.

Table 2 shows also comparison with values obtained in other parts of the world. The average $C_{x}$ value in the present work is within the range and averages obtained worldwide and in other countries listed in the table. 
Table 2 Comparison of indoor radon concentration, $C_{x}\left(\mathrm{~Bq} \mathrm{~m}^{-3}\right)$, in this work with those obtained in some countries in different parts of the world (UNSCEAR 2000)

\begin{tabular}{|c|c|c|c|c|}
\hline Country & Range & Av. $C_{x}$ & Country & Av. $C_{x}$ \\
\hline Pakistan $^{\mathrm{a}}$ & $19-57$ & 40 & W. Germany & $(40)^{\mathrm{d}}$ \\
\hline Cyprus $^{\mathrm{b}}$ & $14 \pm 3-74 \pm 6$ & 29.3 & U.S. & $(35)^{\mathrm{d}}$ \\
\hline$(\text { Greece })^{\mathrm{b}}$ Atica & $5.6 \pm 1.8-161 \pm 12$ & 27.6 & Canada & $(34.4)^{\mathrm{d}}$ \\
\hline$(\text { Greece })^{\mathrm{b}}$ Crete & $1.7 \pm 0.4-141 \pm 12$ & 23.4 & U.K. & $(20)^{\mathrm{d}}$ \\
\hline Spain $^{c}$ & $\begin{array}{l}21 \% \text { above } 148-200 \\
12 \% \text { above } 200\end{array}$ & 69.5 & & \\
\hline Worldwide & & $\left(40 \mathrm{~Bq} \mathrm{~m}^{-3}\right)^{\mathrm{e}}$ & & \\
\hline This work & $\begin{array}{l}85 \% \text { ranged } 20 \pm 2-58 \pm 4 \\
15 \% \text { ranged } 100 \pm 12-378 \pm 20\end{array}$ & $57 \pm 5$ & & \\
\hline
\end{tabular}

${ }^{\text {a }}$ Rahman et al. (2008)

b Nicolopoulos and Louizi (2008)

c Barros-Dios et al. (2007)

d These values were cited by Barros-Dios et al. (2007)

e UNSCEAR (2000)

\section{Measurements of Rn Concentration in the Atmospheric Air}

$\mathrm{Rn}$ measurements in the atmospheric air in Khiam were undertaken in some corresponding gardens of the studied homes at five locations in the town within the summer time period while doing indoor measurements. The procedure for the measurements was described in Sect. 3.3. Table 3 presents the comparison between radon concentration, $C_{x \mathrm{a}}$, in outdoor spaces with the corresponding individual indoor radon concentration, $C_{x}$, for each given dwelling in the corresponding zone in the summer period II.

Rn concentration, $C_{x}$, inside individual homes located in corresponding different zones in the town are given as: $30 \pm 4 \mathrm{~Bq} \mathrm{~m}^{-3}$ (West Zone-1), $26 \pm 3 \mathrm{~Bq} \mathrm{~m}^{-3}$ (West Zone-2), $25 \pm 3 \mathrm{~Bq} \mathrm{~m}^{-3}$ (North Zone-1), $25 \pm 4 \mathrm{~Bq} \mathrm{~m}^{-3}$ (North Zone-2), and $17 \pm 3 \mathrm{~Bq} \mathrm{~m}^{-3}$ (East Zone), as compared with the atmospheric results given as: $37 \pm 4$, $26 \pm 3,41 \pm 3,34 \pm 4$, and $31 \pm 4 \mathrm{~Bq} \mathrm{~m}^{-3}$, respectively. Also the ratios of atmospheric $C_{x \mathrm{a}}$ to indoor $C_{x}$ are given as a measure of $\mathrm{Rn}$ exchange rate between the indoor and outdoor spaces.

Some atmospheric values are somewhat higher than the indoor ones. This could be due to the close distance from the detector to the ground surface as compared to the house level in the field at which the atmospheric radon was measured. Also the ratios of the atmospheric radon concentration to the indoor radon concentration confirm the high level $C_{x}$ in the Northern Zone location, as shown in Table 3. The most important fact is that the actual Rn level in the indoor spaces and the type of indoor building materials is related as is discussed in the following section.

\section{Granite Countertops and Kitchen Rn}

Table 4 presents the Rn concentration, $C_{x}$, in the dosimeter chamber obtained from $\mathrm{Rn}$ emanation at the surface of the corresponding granitic tiles. The $\mathrm{Rn}$ aerial exhalation rate, $E\left(\mathrm{~Bq} \mathrm{~m}^{-2} \mathrm{~h}^{-1}\right)$, obtained in granite was calculated using Eq. 2.

Table 4 shows the identified granite types commonly used in the study's homes and the results of the exhalation rates, $E_{\mathrm{p}}$ and $E_{\mathrm{up}}$, from polished and unpolished sides and their sums, $E_{\mathrm{s}}$, respectively, for each granite type. The sums varied from a minimum of 0.049 to a maximum of $1.950 \mathrm{~Bq} \mathrm{~m}^{-2} \mathrm{~h}^{-1}$ with an average of $0.384 \mathrm{~Bq} \mathrm{~m}^{-2} \mathrm{~h}^{-1}$. The highest values are obtained from two granite types (Giallo-California and Juparana-Bordeaux). These exhalation rates into the kitchen space from both sides of granite countertops contribute an important increase of $\mathrm{Rn}$ concentration to indoor spaces in addition to other sources.

Of the 20 granite types examined, about 12 types produced equal exhalation rate from each side and only five granite types produced a greater exhalation rate from the unpolished side than from the polished one. This may be due to the polishing process, which minimizes the surface porosity of the granitic tiles. This could be also due to the inhomogeneous distribution of radium, ${ }^{226} \mathrm{Ra}$, the parent of ${ }^{222} \mathrm{Rn}$, within the granitic tile, as reflected in two samples for each of the granite types, Giallo-California and Bluepearl, shown in Table 4.

The granite source contribution of $\mathrm{Rn}$ concentration, $C_{x \mathrm{~g}}$, in a space of a given volume, can be calculated using the following equation (Chen et al. 2010):

$C_{x \mathrm{~g}}=E_{\mathrm{A}} \cdot A / V \cdot \lambda=\left(E_{\mathrm{A}} \cdot A \cdot \tau_{1 / 2}\right) / V \ln 2$, 
Table 3 Comparison between $\mathrm{Rn}$ atmospheric concentration, $C_{x \mathrm{a}}\left(\mathrm{Bq} \mathrm{m}^{-3}\right)$, and indoor radon, $C_{x}\left(\mathrm{~Bq} \mathrm{~m}^{-3}\right)$, obtained in the studied corresponding homes during the summer (time period II)

\begin{tabular}{|c|c|c|c|c|c|}
\hline Zone location & West-1 & West-2 & North-1 & North-2 & East \\
\hline Field codes & KH-1 & KH-2 & KH-3 & KH-4 & KH-5 \\
\hline$C_{x \mathrm{a}}\left(\mathrm{Bq} \mathrm{m}^{-3}\right)$ & $37 \pm 4$ & $26 \pm 3$ & $41 \pm 3$ & $34 \pm 4$ & $31 \pm 4$ \\
\hline$C_{x}\left(\mathrm{~Bq} \mathrm{~m}^{-3}\right)$ & $30 \pm 4$ & $26 \pm 3$ & $25 \pm 3$ & $25 \pm 4$ & $17 \pm 3$ \\
\hline Ratio $C_{x a} / C_{x}$ & 1.23 & 1.0 & 1.64 & 1.34 & 1.8 \\
\hline
\end{tabular}

Table $4 \mathrm{Rn}$ concentration, $C_{x \mathrm{p}}\left(\mathrm{Bq} \mathrm{m}^{-3}\right)$, in the detector chamber obtained from polished and $C_{x u p}\left(\mathrm{~Bq} \mathrm{~m}{ }^{-3}\right)$, from unpolished, sides of granite tiles

\begin{tabular}{|c|c|c|c|c|c|c|}
\hline Granite types & $\begin{array}{l}\text { Polished } \\
C_{x \mathrm{p}}\left(\mathrm{Bq} \mathrm{m}^{-3}\right)\end{array}$ & $\begin{array}{l}\text { Unpolished } \\
C_{x \text { up }}\left(\mathrm{Bq} \mathrm{m}^{-3}\right)\end{array}$ & $\begin{array}{l}\text { Polished } \\
E_{\mathrm{p}}\end{array}$ & $\begin{array}{l}\text { Unpolished } \\
E_{\text {up }}\end{array}$ & $\begin{array}{l}\text { Sum } \\
E_{\mathrm{s}}\end{array}$ & $\begin{array}{l}7 \tau_{1 / 2} \\
C_{x g}\end{array}$ \\
\hline 1-Tan Brown & $108 \pm 15$ & $107 \pm 12$ & 0.068 & 0.068 & 0.136 & 11 \\
\hline 2-Blue Pearl 1 & $52 \pm 8$ & $57 \pm 8$ & 0.033 & 0.036 & 0.069 & 5 \\
\hline 3-Galaxy & $46 \pm 7$ & $49 \pm 5$ & 0.029 & 0.031 & 0.060 & 5 \\
\hline 4-Green Butterfly & $47 \pm 5$ & $61 \pm 15$ & 0.030 & 0.039 & 0.068 & 5 \\
\hline 5-Kashmir Gold & $47 \pm 5$ & $61 \pm 15$ & 0.030 & 0.039 & 0.068 & 5 \\
\hline 6-Multicolor Red & $70 \pm 3$ & $166 \pm 14$ & 0.044 & 0.105 & 0.149 & 12 \\
\hline 7-Jupurana-Beaurdeaux & $1,562 \pm 68$ & $134 \pm 31$ & 0.987 & 0.085 & 1.072 & 83 \\
\hline 8-Multicolor & $45 \pm 3$ & $61 \pm 5$ & 0.028 & 0.039 & 0.067 & 5 \\
\hline 9-Baltic Brown & $204 \pm 18$ & $183 \pm 11$ & 0.129 & 0.116 & 0.245 & 19 \\
\hline 10-Rosa Betta & $75 \pm 5$ & $92 \pm 4$ & 0.047 & 0.058 & 0.106 & 8 \\
\hline 11-Madora Gold & $131 \pm 21$ & $230 \pm 16$ & 0.083 & 0.145 & 0.228 & 18 \\
\hline 12-Paradiso Bash & $51 \pm 5$ & $51 \pm 3$ & 0.032 & 0.032 & 0.064 & 5 \\
\hline 13-Shangrella & $356 \pm 21$ & $546 \pm 30$ & 0.225 & 0.345 & 0.570 & 44 \\
\hline 14-Lilas Gerais & $442 \pm 30$ & $437 \pm 27$ & 0.279 & 0.276 & 0.556 & 43 \\
\hline 15-Giallo California 1 & $976 \pm 23$ & $2,109 \pm 84$ & 0.617 & 1.333 & 1.950 & 151 \\
\hline 16-Kinawa & $287 \pm 19$ & $292 \pm 19$ & 0.181 & 0.185 & 0.366 & 28 \\
\hline 17-Blue Pearl 2 & $46 \pm 3$ & $31 \pm 3$ & 0.029 & 0.020 & 0.049 & 4 \\
\hline 18-Giallo California 2 & $765 \pm 42$ & $1,056 \pm 18$ & 0.483 & 0.667 & 1.151 & 89 \\
\hline 19-Tropical Gold & $584 \pm 28$ & $357 \pm 14$ & 0.369 & 0.226 & 0.595 & 46 \\
\hline 20-Porino & $83 \pm 4$ & $88 \pm 3$ & 0.052 & 0.056 & 0.108 & 8 \\
\hline
\end{tabular}

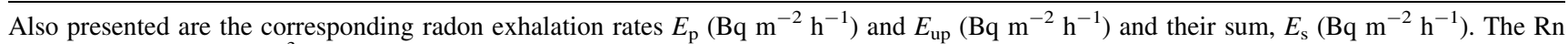
contribution, $C_{x \mathrm{~g}}\left(\mathrm{~Bq} \mathrm{~m}^{-3}\right)$, from granites to kitchen indoor space is also displayed

where $E_{\mathrm{A}}$ is the Rn exhalation rate, $A$ is the surface area of the granite countertop, $V$ is the volume containing the radon source, and $\tau_{1 / 2}$ is radon half-life $(92 \mathrm{~h})$. For a radon source to attain equilibrium in a closed kitchen volume, about $7 \tau_{1 / 2}$ of time is assumed. Using Eq. 4 and the sum of the exhalation rates listed in Table 4 , and assuming a granite countertop with an area of $3 \mathrm{~m}^{2}$ and a closed kitchen volume of $36 \mathrm{~m}^{3}$ (as is usually in Lebanon), the calculated $C_{x \mathrm{~g}}$ rates are listed in Table 4.

$C_{x \mathrm{~g}}$ ranged from $4 \mathrm{~Bq} \mathrm{~m}^{-3}$ (Blue-Pearl 2) to $151 \mathrm{~Bq} \mathrm{~m}^{-3}$ (Giallo-California 1), among the granites. The highest contributions of 151,89 , and $83 \mathrm{~Bq} \mathrm{~m}^{-3}$ are produced by Giallo-California-1, Giallo-California-2, and JuparanaBordeaux granites, respectively. Exhalation rates calculated from granites in this study are close to the corresponding ones measured by other researchers (Environmental Health and Engineering 2008), with exhalations measured at different surface locations on the slab where a high exhalation rate in Juparana-Bordeaux granites was obtained.

Table 4 shows that most of the granites contribute lower radon concentrations to indoor kitchen spaces as compared with the maximum allowable level of $100 \mathrm{~Bq} \mathrm{~m}^{-3}$, set by WHO. This result for the kitchen was obtained based on our assumption of a closed kitchen space, without taking into consideration the ventilation effect, which will reduce the Rn level. The present results show that precaution should be taken when using those granite countertop types that produce a high radon flux in indoor spaces. 
Table 5 Average annual effective dose, $E\left(\mathrm{mSv} \mathrm{a}^{-1}\right)$, absorbed by the residents in the listed individual homes in Khiam Town

\begin{tabular}{lcc}
\hline Home code & Mean $C_{x}$ & $E\left(\mathrm{mSv} \mathrm{a}^{-1}\right)$ \\
\hline KH-2 & $56 \pm 4$ & $1.41 \pm 0.10$ \\
KH-7 & $118 \pm 11$ & $2.98 \pm 0.28$ \\
KH-14 & $70 \pm 12$ & $1.77 \pm 0.30$ \\
KH-29 & $40 \pm 4$ & $1.01 \pm 0.10$ \\
KH-30 & $143 \pm 13$ & $3.61 \pm 0.33$ \\
KH-39 & $343 \pm 20$ & $8.65 \pm 0.50$ \\
\hline
\end{tabular}

\section{Health Assessment of Radon Concentrations Measured in South Lebanon Homes}

Based on the obtained results of radon $\left(C_{x}\right)$ in the studied homes and the exposure of the occupants of those homes to radon and radiation of its progenies, it is possible to assess the health impact of such radiation on people living indoors. Table 1 shows that rooms in some homes (KH-2, KH-7, KH-14, KH-29, KH-30, and KH-39) in Khiam Town exhibit a high average Rn concentration well above the limit of $100 \mathrm{~Bq} \mathrm{~m}^{-3}$ set by WHO. According to UNSCEAR reports (UNSCEAR 1993, 2000) and the research of other researchers (Sajo'-Bohus et al. 1999; Papaefthymiou and Gouseti 2008; Environmental Health and Engineering 2008), the annual effective dose, $E\left(\mathrm{mSv} \mathrm{a}^{-1}\right)$, absorbed by the public from radon and its progenies is estimated by the following formula:

$E=0.4 \times 0.8 \times 8760 \times 9.0 \times 10^{-6} C_{x}$,

where 0.4 is the equilibrium factor, 0.8 is the occupation factor of the home residents, 8,760 is the number of hours per year and $9.0 \times 10^{-6}\left(\mathrm{mSv} \mathrm{Bq} \mathrm{m}{ }^{-3} \mathrm{~h}^{-1}\right)$ is the dose effective factor, and $C_{x}$ is the indoor radon concentration. Using this formula and the total averaged $C_{x}$ in each of the mentioned homes, the calculated $E\left(\mathrm{mSv} \mathrm{a}^{-1}\right)$ for each home in Khiam Town is presented in Table 5.

Each of the six dwellings in Table 5 averaged an $E$ reading ranging from $1.01 \pm 0.10$ to $8.65 \pm 0.50 \mathrm{mSv} \mathrm{a}^{-1}$. All these values, except one, are above the limit of $1 \mathrm{mSva}^{-1}$ set by UNSCEAR for building materials. Five homes listed in Table 5 are above the limit of $1.2 \mathrm{mSv} \mathrm{a}^{-1}$ set for Central Europe. A drastic high annual effective dose of exposure was obtained in three dwellings (KH-7, KH-30, and KH-39): $2.98 \pm 0.28$, $3.61 \pm 0.33$, and $8.65 \pm 0.50 \mathrm{mSv}^{-1}$ respectively, with the highest one in dwelling KH-39 in Khiam, Western Zone. For those residents, whose dwellings produced a high level of annual effective dose, recommendations were given to them to take remedial action in their homes.

The kind of action is conditioned by the geological structure and subsurface on which the dwellings are built, and mitigation of $\mathrm{Rn}$ indoors could be sometimes very costly. For the studied area in the present work, the possible executable remedial actions in the social environment were recommended within the following guidelines: (1) Construct an appropriate ventilation system in the rooms emanating high radon levels above the permissible limit, in order to extract indoor air to the outdoor spaces. (2) Leave the internal doors open to allow Rn gas exchange within the dwelling and facilitate ventilation to reduce Rn level within the home space. (3) Bathrooms with showers should have their own ventilation system. (4) Avoid construction using granite with high exhalation rates in inner space of future home buildings. In addition, it is recommended to the authorities to monitor imported granites at the border entries of the country for high radium and radon emissions to prevent the use of such materials, which can cause heath damage to the public.

\section{Conclusions}

The presence of a high concentration of radon and its inhalation indoors is a major concern of the public worldwide. Due to that concern, radon concentration indoors and outdoors in South Lebanon have been measured in three seasonal periods during the year in 2010 . Based on the present study, we conclude that: (1) Overall averaged radon concentrations, $C_{x}$, for all measured dwellings, ranged from $20 \pm 2$ to $343 \pm 20 \mathrm{~Bq} \mathrm{~m}^{-3}$ in Khiam Town in South Lebanon. While opening home doors and windows during summer period can produce lower indoor Rn concentration as opposed to closed doors and windows in winter season, the present study showed that many dwellings did not have lowered $C_{x}$ during summer time, indicating that opening doors and windows must be done continuously to be effective. This leads to the recommendation to set up a ventilation system in home space. This is the major factor in reducing Rn level in the indoor spaces. (2) Six of the studied dwellings exhibited an annual radon effective dose, $E$, above the limit of $1 \mathrm{mSv} \mathrm{a}^{-1}$ set by UNSCEAR for building materials, while five dwellings were above the limit of $1.2 \mathrm{mSv} \mathrm{a}^{-1}$ set for Central Europe. (3) Measurements showed a dependence of radon concentrations on dwellings located close to the geological fault structures encountered in the area. Also, higher altitudes above the sea level have exhibited a reduction in $\mathrm{Rn}$ levels inside homes.

Acknowledgments The main author (M.A. Kobeissi) would like to thank the director of the Lebanese Atomic Energy Commission, Dr. Bilal Nsouli, for providing the facility for the establishment of the radon laboratory. Also many thanks go to Mona Yassin and Zahra'a Mantash for their hard work in getting their Master's degree within the project. Our thanks also go to Mr. Redha Shamoun for his help in 
creating the contacts with the residents in the study area. Thanks goes to Dr. Charles Tabet for the English editing. The authors would like to thank all the families who participated in the project and the municipality of Khiam Town for facilitating the access to their domains. Financial support for the study was provided by the Lebanese National Council for Scientific Research and is highly appreciated.

Open Access This article is distributed under the terms of the Creative Commons Attribution License which permits any use, distribution, and reproduction in any medium, provided the original author(s) and the source are credited.

\section{References}

Abdallah, S.M., R.R. Habib, R.Y. Nuwayhid, M. Chatila, and G. Katul. 2007. Radon measurements in well and spring water in Lebanon. Radiation Measurements 42(2): 298-303.

Abu-Jarad, F., J.H. Fremline, and R. Bul. 1980. A study of radon emitted from construction materials using plastic $\alpha$-track detectors. Physics in Medicine \& Biology 25(6): 483-694.

Al-Jarallah, M.I. 2001. Radon exhalation from granite used in Saudi Arabia. Journal of Environmental Radioactivity 53(1): 91-98.

Barros-Dios, J.M., A. Ruano-Ravina, J. Gastelu-Iturri, and A. Figueras. 2007. Factors underlying residential radon concentration: Results from Galcia (Spain). Environmental Research 103(2): 185-190.

Chen, J., N.M. Rahman, and I.A. Atiya. 2010. Radon exhalation from building materials for decorative use. Journal of Environmental Radioactivity 101(4): 317-322.

El-Amri, E.A., M.I. Al-Jarallah, F. Abu-Jarad, and E.A. Fazal-yrRehman. 2003. Uniformity in radon exhalation from construction materials using can technique. Radiation Measurements 36(3): 453-456.

El-Dine, N.W., A. El-Shershaby, F. Ahmed, and A.S. Abdel-Haleem. 2001. Measurements of radioactivity and radon exhalation rate in different kinds of marbles and granites. Applied Radiation and Isotopes 55(6): 853-860.

Environmental Health and Engineering. 2008. Assessing exposure to radon and radiation from granite countertops. Needham, MA: Environmental Health and Engineering.

Font, L.L., C. Baixeras, C. Domingo, and F. Ferdandez. 1999. Experimental and theoretical study of radon levels and entry mechanisms in a Mediterranean climate house. Radiation Measurements 31: 277-282.

Hassan, M.N.M., M. Hosoda, K. Iwaoka, A. Sorimachi, J. Miroslaw, K. Chutima, S.S. Kumar, and T. Ishikawa. 2011. Simultaneous measurement of radon and thoron released from building materials used in Japan. Progress in Nuclear Science and Technology 1: 404-407.

Khan, A.J., R. Prasad, and R.K. Tyagi. 1992. Measurements of exhalation rate from some building materials. Nuclear Tracks and Radiation Measurements 20(4): 609-610.

Kobeissi, M.A., O. El-Samad, K. Zahraman, S. Melki, F. Bahsoun, and K.M. Abumrad. 2008. Natural radioactivity measurements in building materials in South Lebanon. Journal of Environmental Radioactivity 99(8): 1279-1288.

Kobeissi, M.A., O. El-Samad, and I. Rachidi. 2013. Health assessment of natural radioactivity and radon exhalation rate in granites used as building materials in Lebanon. Radiation Protection Dosimetry 153(3): 342-351.

Lawrence, C.E., R.A. Akber, A. BollhÖfer, and P. Martin. 2009. Radon-222 exhalation from open ground on and around uranium mine in the wet-dry tropics. Journal of Environmental Radioactivity 100(1): 1-8.

Maged, A.F., and F.E. Ashraf. 2005. Radon exhalation rate of building materials used in Egypt. Environmental Geochemistry and Health 27(5-6): 485-489.

Maged, A.F., and E. Borham. 1997. A study of radon emitted from various building materials using alpha track detectors. Radiation Measurements 28(1): 613-617.

Mireles, F., M.L. Garcia, L.L. Quirino, J.I. Davila, J.L. Pinedo, C. Rios, M.E. Montero, L. Colmenero, and L. Villaba. 2007. Radon survey related to construction materials and soils in Zacatecas, Mexico using LR-115. Radiation Measurements 42(8): 1397-1403.

Nassiri, P., H. Ebrahimi, and P.J. Shalkouhi. 2011. Evaluation of radon exhalation rate from granite stone. Journal of Scientific \& Industrial Research 70(3): 230-231.

Nazaroff, W.W., and A.V. Nero Jr. (eds.) 1988.Radon and its decay products in indoor air. New York: John Wiley and Sons.

Nicolopoulos, D., and A. Louizi. 2008. Study of indoor radon and radon in drinking water in Greece and Cyprus: Implication to exposure and dose. Radiation Measurements 43(7): 1305-1314.

Papaefthymiou, H., and O. Gouseti. 2008. Natural radioactivity and associated radiation hazards in building materials used in Peloponnese, Greece. Radiation Measurements 43(8): 1453-1457.

Rahman, S.U., J. Anwar, and Matiullah. 2008. Measurement of indoor radon concentration levels in Islamabad, Pakistan. Radiation Measurements 43(S1): S401-S404.

Sajo'-Bohus, L., J. Pa'falvi, F. Urbani, D. Castro, E.D. Greaves, and J.A. Liendo. 1999. Environmental Gamma radon dosimetry in Venezuela. Radiation Measurements 31: 283-286.

Sharma, D.K., A. Kumar, M. Kumar, and S. Singh. 2003. Study of uranium, radium and radon exhalation rate in soil samples from some areas of Kangra District, Himachal Pradesh, India, using solid-state nuclear track detectors. Radiation Measurements 36: 363-366.

Singh, B., and H.S. Virk. 1996. Effect of soil and sand moisture content on radon diffusion using plastic track etched detector. Radiation Measurements 26(1): 49-50.

Singh, S., R. Malhotra, J. Kumar, and L. Singh. 2001. Indoor radon measurements in dwellings of Kulu area, Himachal Pradesh, using solid state nuclear track detectors. Radiation Measurements 34: 505-508.

Singh, S., D.K. Sharma, and A. Kumar. 2004. Environmental radon studies using solid state nuclear track detectors. Journal of Environmental Radioactivity 76(3): 369-376.

Singh, H., J. Singh, S. Singh, and B.S. Bajwa. 2008. Radon exhalation rate and uranium estimation study of some soil and rock samples from Tusham ring complex, India using SSNTD. Radiation Measurements 43(S1): S459-S462.

UNSCEAR (United Nations Scientific Committee on the Effects of Atomic Radiation). 1993. United Nations Scientific Committee on the effects of atomic radiation sources and effects of ionizing radiation. New York: United Nations.

UNSCEAR (United Nations Scientific Committee on the Effects of Atomic Radiation). 2000. United Nations Scientific Committee on the effects of atomic radiation. Annex A: Exposure from natural sources. New York: United Nations.

Walley, C.D. 1988. A braided strike-slip model for the northern continuation of the Dead Sea Fault and its implications for Levantine tectonics. Tectonophysics 145(1-2): 63-72.

Walley, C.D. 1998. Some outstanding issues in the geology of Lebanon and their importance in the tectonic evolution of the Levantine region. Tectonophysics 298(1-3): 37-62.

WHO (World Health Organization). 2009. Handbook on indoor radon. Geneva: World Health Organization. 